Journal of Applied Pharmaceutical Science Vol. 5 (11), pp. 069-072, November, 2015

Available online at http://www.japsonline.com

DOI: $10.7324 / \mathrm{JAPS} .2015 .501111$

ISSN 2231-3354 (cc) BY-NC-SA

\title{
Chemical Constituents of Hoya buotii Kloppenb.
}

\author{
Virgilio D. Ebajo Jr. ${ }^{1}$, Robert Brkljača ${ }^{2}$, Sylvia Urban ${ }^{2}$, Consolacion Y. Ragasa ${ }^{1,3 *}$ \\ ${ }^{1}$ Chemistry Department, De La Salle University, 2401 Taft Avenue, Manila 1004, Philippines. ${ }^{2}$ School of Applied Sciences (Discipline of Chemistry), \\ Health Innovations Research Institute (HIRi) RMIT University, GPO Box 2476V Melbourne, Victoria 3001, Australia. ${ }^{3}$ Chemistry Department, De La \\ Salle University Science \& Technology Complex Leandro V. Locsin Campus, Biñan City, Laguna 4024, Philippines.
}

\begin{tabular}{|c|c|}
\hline ARTICLE INFO & ABSTRACT \\
\hline $\begin{array}{l}\text { Article history: } \\
\text { Received on: } 23 / 08 / 2015 \\
\text { Revised on: } 07 / 09 / 2015 \\
\text { Accepted on: } 03 / 10 / 2015 \\
\text { Available online: } 27 / 11 / 2015\end{array}$ & \multirow[t]{2}{*}{$\begin{array}{l}\text { Chemical investigation of the dichloromethane extracts of Hoya buotii Kloppenb. afforded taraxerone (1), } \\
\text { taraxerol (2), a mixture of } \beta \text {-sitosterol (3a) and stigmasterol }(\mathbf{3 b}) \text { in about } 2: 1 \text { ratio, and a mixture of } \alpha \text {-amyrin } \\
\text { cinnamate }(\mathbf{4 a}) \text { and } \beta \text {-amyrin cinnamate }(\mathbf{4 b}) \text { in about } 1: 2 \text { ratio from the stems; } \mathbf{1}, \mathbf{2} \text {, and } \mathbf{3 a} \text { from the roots; a } \\
\text { mixture of } \mathbf{4 a} \text { and } \mathbf{4 b} \text { in about } 3: 2 \text { ratio from the flowers; and } \mathbf{3 a} \text {, squalene }(\mathbf{5}) \text { and saturated hydrocarbons from } \\
\text { the leaves. The structures of } \mathbf{1 - 5} \text { were identified by comparison of their NMR data with those reported in the } \\
\text { literature. }\end{array}$} \\
\hline $\begin{array}{l}\text { Key words: } \\
\text { Hoya buotii, Apocynaceae, } \\
\text { taraxerone, taraxerol, } \beta \text { - } \\
\text { sitosterol, stigmasterol, } \alpha- \\
\text { amyrin cinnamate, } \beta \text {-amyrin } \\
\text { cinnamate, squalene. }\end{array}$ & \\
\hline
\end{tabular}

\section{INTRODUCTION}

Hoya plants are also called wax plants due to the waxy appearance of their leaves or flowers. There are at least 109 species of Hoyas found in the Philippines, 88 of these are endemic to the country (Aurigue, 2013). Hoya buotii Kloppenb. is an endemic Philippine ornamental plant which was first collected from Mt. Banahaw, Quezon Province and was also found in the Sierra Madre Mountain Range of Luzon and Mt. Halcon in Mindoro (Aurigue, 2013).

The plant bears a cluster of creamy yellow flowers which resemble a starfish with reddish center (Aurigue, 2013). There are no reported chemical studies and biological activities on $H$. buotii. This study is part of our research on the chemical constituents of endemic Philippine Hoyas. We earlier reported the isolation of lupenone (I) and lupeol (II) from the roots; II, squalene (III) and $\beta$-sitosterol (IV) from the leaves; and betulin (V) from the stems of $H$. mindorensis Schlechter (Ebajo et al.,

\footnotetext{
* Corresponding Author

Email: consolacion.ragasa@dlsu.edu.ph
}

2014). In another study, we reported the isolation of II, $\alpha$ amyrin (VI), $\beta$-amyrin (VII), lupeol acetate (VIII), $\alpha$-amyrin acetate (IX), and $\beta$-amyrin acetate $(\mathbf{X})$ from the stems; and VI, bauerenol (XI), III, lutein (XII), IV, and stigmasterol (XIII) from the leaves of H. multiflora Blume (Ebajo et al., 2015a). Recently, the isolation of $\beta$-amyrin cinnamate (XIV) and taraxerol (XV) from the stems; and XV, triglycerides (XVI), chlorophyll a (VII), and a mixture of IV and XIII from the leaves of $H$. wayetii Kloppenb has been reported (Ebajo et al., 2015b). We report herein the isolation of taraxerone (1), taraxerol (2), a mixture of $\beta$ sitosterol (3a) and stigmasterol (3b) in about 2:1 ratio, and a mixture of $\alpha$-amyrin cinnamate (4a) and $\beta$-amyrin cinnamate (4b) in about 1:2 ratio from the stems; $\mathbf{1}, \mathbf{2}$, and $\mathbf{3 a}$ from the roots; a mixture of $\mathbf{4 a}$ and $\mathbf{4 b}$ in about 3:2 ratio from the flowers; and $\mathbf{3 a}$, squalene (5), and saturated hydrocarbons from the leaves of $H$. buotii. To our knowledge this is the first report on the isolation of these compounds from $H$. buotii. Chemical structures of taraxerone (1), taraxerol (2), $\beta$-sitosterol (3a), stigmasterol (3b), $\alpha$-amyrin cinnamate (4a), $\beta$-amyrin cinnamate $(\mathbf{4 b})$, and squalene (5) from H. buotii. 


\section{MATERIALS AND METHODS}

\section{General experimental procedure}

${ }^{1} \mathrm{H}(500 \mathrm{MHz})$ and ${ }^{13} \mathrm{C}(125 \mathrm{MHz}) \mathrm{NMR}$ spectra were acquired in $\mathrm{CDCl}_{3}$ on a $500 \mathrm{MHz}$ Agilent DD2 NMR spectrometer with referencing to solvent signals ( $\delta 7.26$ and $77.0 \mathrm{ppm})$. Column chromatography was performed with silica gel 60 (70-230 mesh). Thin layer chromatography was performed with plastic backed plates coated with silica gel $\mathrm{F}_{254}$ and the plates were visualized by spraying with vanillin/ $\mathrm{H}_{2} \mathrm{SO}_{4}$ solution followed by warming.

\section{Sample collection}

The sample was collected from a garden in Caloocan City, Philippines in March 2014. The sample was authenticated at the Philippine National Herbarium, Botany Division, National Museum of the Philippines. It was identified as Hoya buotii Kloppenb. by Danilo N. Tandang.

\section{General isolation procedure}

A glass column 18 inches in height and 1.0 inch internal diameter was packed with silica gel. The crude extracts were fractionated by silica gel chromatography using increasing proportions of acetone in $\mathrm{CH}_{2} \mathrm{Cl}_{2}(10 \%$ increment) as eluents. Fifty milliliter fractions were collected. All fractions were monitored by thin layer chromatography. Fractions with spots of the same $R_{f}$ values were combined and rechromatographed in appropriate solvent systems until TLC pure isolates were obtained. A glass column 12 inches in height and 0.5 inch internal diameter was used for the rechromatography. Two milliliter fractions were collected. Final purifications were conducted using Pasteur pipettes as columns. One milliliter fractions were collected.

\section{Isolation of the chemical constituents of the stems}

The air-dried stems of $\mathrm{H}$. buotii (71.5 g) were ground in a blender, soaked in $\mathrm{CH}_{2} \mathrm{Cl}_{2}$ for 3 days and then filtered. The solvent was evaporated under vacuum to afford a crude extract $(2.3 \mathrm{~g})$ which was chromatographed using increasing proportions of acetone in $\mathrm{CH}_{2} \mathrm{Cl}_{2}$ at $10 \%$ increment. The $10 \%$ acetone in $\mathrm{CH}_{2} \mathrm{Cl}_{2}$ fraction was rechromatographed $(4 \times)$ using $5 \%$ EtOAc in petroleum ether to afford a mixture of $\mathbf{4 a}$ and $\mathbf{4 b}(3 \mathrm{mg})$ after washing with petroleum ether. The $20 \%$ acetone in $\mathrm{CH}_{2} \mathrm{Cl}_{2}$ fraction was rechromatographed $(3 \times)$ using $10 \%$ EtOAc in petroleum ether to afford $1(6 \mathrm{mg})$ after washing with petroleum ether. The $30 \%$ acetone in $\mathrm{CH}_{2} \mathrm{Cl}_{2}$ fraction was rechromatographed $(3 \times)$ using $20 \%$ EtOAc in petroleum ether to afford $2(12 \mathrm{mg})$ after washing with petroleum ether. The $40 \%$ acetone in $\mathrm{CH}_{2} \mathrm{Cl}_{2}$ fraction was rechromatographed $(2 \times)$ using $\mathrm{CH}_{3} \mathrm{CN}: \mathrm{Et}_{2} \mathrm{O}: \mathrm{CH}_{2} \mathrm{Cl}_{2}$ $(0.5: 0.5: 9, \mathrm{v} / \mathrm{v})$ to yield a mixture of $\mathbf{3 a}$ and $\mathbf{3 b}(8 \mathrm{mg})$ after washing with petroleum ether.

\section{Isolation of the chemical constituents of the roots}

The air-dried roots of $H$. buotii $(7.2 \mathrm{~g})$ were ground in a blender, soaked in $\mathrm{CH}_{2} \mathrm{Cl}_{2}$ for 3 days and then filtered. The solvent was evaporated under vacuum to afford a crude extract $(0.1 \mathrm{~g})$ which was chromatographed using increasing proportions of acetone in $\mathrm{CH}_{2} \mathrm{Cl}_{2}$ at $10 \%$ increment. The $20 \%$ acetone in $\mathrm{CH}_{2} \mathrm{Cl}_{2}$ fraction was rechromatographed using $10 \%$ EtOAc in petroleum ether to afford $\mathbf{1}$ (4 $\mathrm{mg}$ ) after washing with petroleum ether.

The $40 \%$ acetone in $\mathrm{CH}_{2} \mathrm{Cl}_{2}$ fraction was rechromatographed using $15 \%$ EtOAc in petroleum ether. The less polar fractions were combined and rechromatographed using the same solvent $(2 \times)$ to afford $2(5 \mathrm{mg})$ after washing with petroleum ether. The more polar fractions were combined and rechromatographed using $20 \%$ EtOAc in petroleum ether to yield 3a $(3 \mathrm{mg})$ after washing with petroleum ether.

\section{Isolation of the chemical constituents of the flowers}

The air-dried flowers of $H$. buotii $(6.0 \mathrm{~g})$ were ground in a blender, soaked in $\mathrm{CH}_{2} \mathrm{Cl}_{2}$ for 3 days and then filtered. The solvent was evaporated under vacuum to afford a crude extract $(0.1 \mathrm{~g})$ which was chromatographed using increasing proportions of acetone in $\mathrm{CH}_{2} \mathrm{Cl}_{2}$ at $10 \%$ increment. The $\mathrm{CH}_{2} \mathrm{Cl}_{2}$ fraction was rechromatographed $(3 \times)$ using $5 \%$ EtOAc in petroleum ether to afford a mixture of $\mathbf{4 a}$ and $\mathbf{4 b}(5 \mathrm{mg})$ after washing with petroleum ether.

\section{Isolation of the chemical constituents of the leaves}

The air-dried leaves of $H$. buotii $(71.5 \mathrm{~g}$ ) were ground in a blender, soaked in $\mathrm{CH}_{2} \mathrm{Cl}_{2}$ for 3 days and then filtered. The solvent was evaporated under vacuum to afford a crude extract $(6.5 \mathrm{~g})$ which was chromatographed using increasing proportions of acetone in $\mathrm{CH}_{2} \mathrm{Cl}_{2}$ at $10 \%$ increment.

The $\mathrm{CH}_{2} \mathrm{Cl}_{2}$ was rechromatographed in petroleum ether. The less polar fractions were combined and rechromatographed in petroleum ether to yield saturated hydrocarbons $(25 \mathrm{mg})$ after washing with petroleum ether.

The more polar fractions were combined and rechromatographed using $1 \%$ EtOAc in petroleum ether to afford $\mathbf{5}$ (9 mg). The $30 \%$ acetone in $\mathrm{CH}_{2} \mathrm{Cl}_{2}$ fraction was rechromatographed $(3 \times)$ using $20 \%$ EtOAc in petroleum ether to afford 3a (6 mg).

\section{Taraxerone (1)}

${ }^{1} \mathrm{H}$ NMR (500 MHz, $\left.\mathrm{CDCl}_{3}\right): \delta 5.54(\mathrm{H}-15), 1.07$ (s, Me-23), 1.06 (s, Me-24), 1.08 (s, Me-25), 0.91 (s, Me-26), 1.13 (s, Me-27), 0.82 (s, Me-28), 0.95 (s, Me-29), 0.89 (s, Me-30); ${ }^{13} \mathrm{C}-$ NMR (125 MHz, $\mathrm{CDCl}_{3}$ ) \&: 38.3 (C-1), 33.6 (C-2), 217.6 (C-3), 47.6 (C-4), 55.8 (C-5), 19.9 (C-6), 37.7 (C-7), 38.9 (C-8), 48.8 (C9), 37.5 (C-10), 17.4 (C-11), 34.1 (C-12), 29.8 (C-13), 157.6 (C14), 117.2 (C-15), 36.7 (C-16), 35.8 (C-17), 48.8 (C-18), 40.6 (C19), 28.8 (C-20), 33.1 (C-21), 35.1 (C-22), 26.1 (C-23), 21.5 (C24),14.8 (C-25), 29.9 (C-26), 25.6 (C-27), 29.8 (C-28), 33.3 (C29), 21.3 (C-30). 

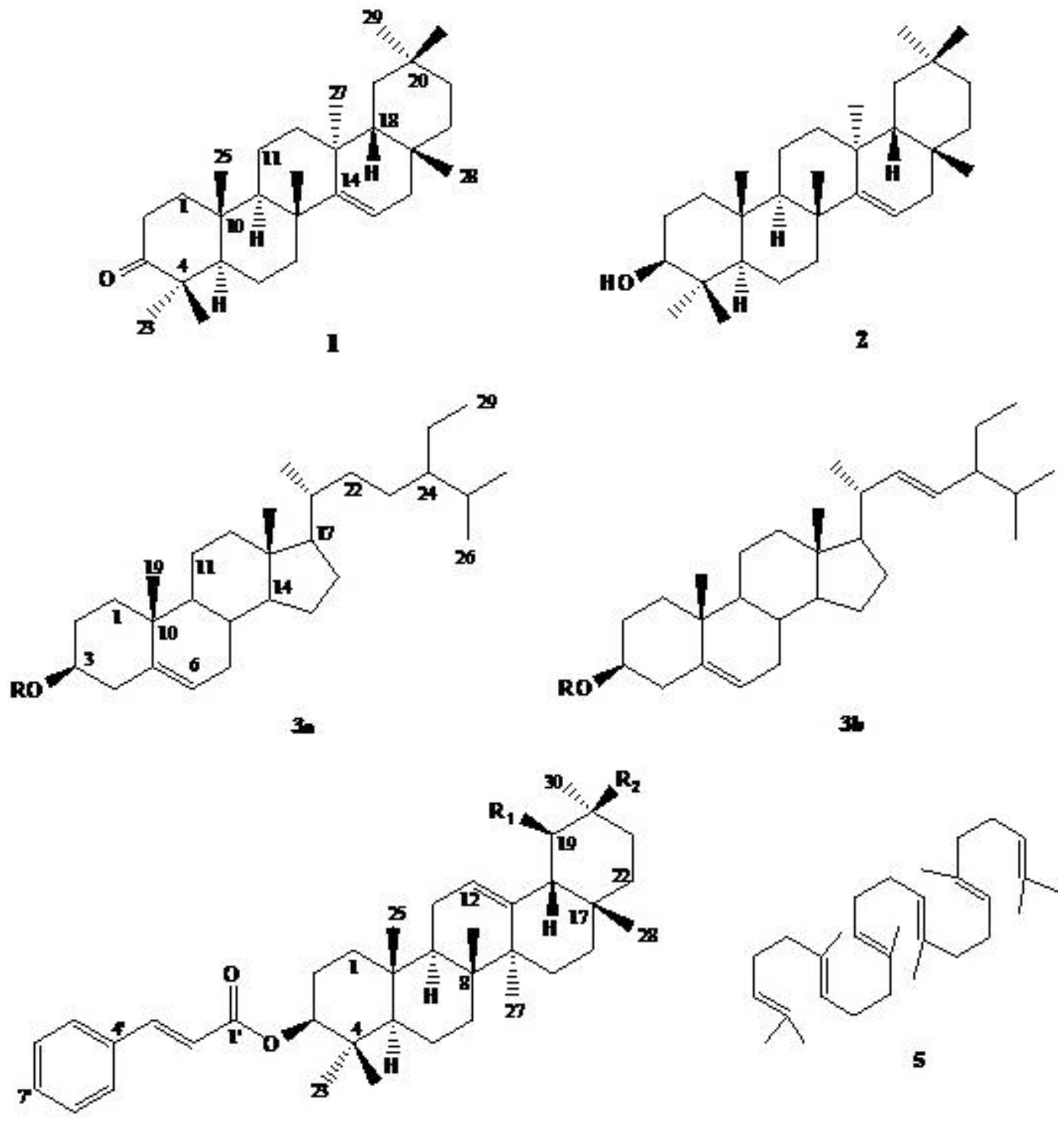

\[ \mathbf{R}_{\mathbf{1}}=\mathrm{CH}_{\mathbf{3}} \mathbf{R}_{\mathbf{2}}=\mathrm{H} \]
$\mathbf{R}_{\mathbf{1}}=\mathrm{H}_{\mathbf{R}} \mathbf{R}_{\mathbf{2}}=\mathrm{CH}_{3}$

\section{Taraxerol (2)}

${ }^{1} \mathrm{H}$ NMR (500 MHz, $\left.\mathrm{CDCl}_{3}\right): \delta 3.20(\mathrm{H}-3), 5.52(\mathrm{H}-14)$, 0.92 (s, Me-23), 0.90 (s, Me-24), 0.97 (s, Me-25), 1.08 (s, Me-26), 0.82 (s, Me-27), 0.80 (s, Me-28), 0.94 (s, Me-29), 0.90 (s, Me-30); ${ }^{13} \mathrm{C}$ NMR (125 MHz, $\mathrm{CDCl}_{3}$ ): $\delta 38.0(\mathrm{C}-1), 27.1$ (C-2), 79.1 (C-3), 39.0 (C-4), 55.5 (C-5), 18.8 (C-6), 35.1 (C-7), 38.8 (C-8), 48.7 (C9), 37.6 (C-10), 17.5 (C-11), 35.8 (C-12), 37.7 (C-13), 158.1 (C14), 116.9 (C-15), 36.7 (C-16), 37.7 (C-17), 49.3 (C-18), 41.3 (C19), 28.8 (C-20), 33.7 (C-21), 33.1 (C-22), 28.0 (C-23), 15.4 (C24), 15.4 (C-25), 29.8 (C-26), 25.9 (C-27), 29.9 (C-28), 33.3 (C29), 21.3 (C-30).

\section{B-Sitosterol (3a)}

${ }^{1} \mathrm{H}$ NMR (500 MHz, $\left.\mathrm{CDCl}_{3}\right): \delta 3.50(\mathrm{~m}, \mathrm{H}-3), 5.35(\mathrm{~d}$, 4.8, H-5), 0.66 (s, Me-18), 0.99 (s, Me-19), 0.93 (d, 6.6, Me-21), $0.84(\mathrm{~d}, J=6.6$, Me-26), $0.83(\mathrm{~d}, J=6.0, \mathrm{Me}-27), 0.86(\mathrm{t}, J=6.0$, Me-29).

\section{Stigmasterol (3b)}

${ }^{1} \mathrm{H}$ NMR (500 MHz, $\mathrm{CDCl}_{3}$ ): $\delta 3.50(\mathrm{~m}, \mathrm{H}-3), 5.33$ (d, $J$ $=4.8, \mathrm{H}-5), 0.68(\mathrm{~s}, \mathrm{Me}-18), 0.99$ (s, Me-19), 1.01 (d, $J=6.6$, Me21), 5.13 (dd, $J=8.4,15.6 \mathrm{~Hz}, \mathrm{H}-22), 5.00$ (dd, $J=8.4,15.0 \mathrm{~Hz}$, $\mathrm{H}-23), 0.84$ (d, $J=6.6 \mathrm{~Hz}, \mathrm{Me}-26), 0.83$ (d, $J=6.0 \mathrm{~Hz}, \mathrm{Me}-27)$, 0.80 (t, $J=6.0 \mathrm{~Hz}, \mathrm{Me}-29)$.

\section{$\alpha$-Amyrin cinnamate (4a)}

${ }^{1} \mathrm{H}$ NMR $\left(500 \mathrm{MHz}, \mathrm{CDCl}_{3}\right): \delta 4.65(\mathrm{dd}, J=6.0,10.1$ $\mathrm{Hz}, \mathrm{H}-3$ ), 5.13 (t, $J=3.8 \mathrm{~Hz}, \mathrm{H}-12$ ), 0.92 (s, Me-23), 0.95 (s, Me24), 1.01 (s, Me-25), 1.03 (s, Me-26), 1.08 (s, Me-27), 0.80 (s, Me28), 0.80 (d, $J=5.9 \mathrm{~Hz}, \mathrm{Me}-29), 0.92$ (d, $J=5.9 \mathrm{~Hz}, \mathrm{Me}-30), 7.67$ 
(d, $\left.J=16.0 \mathrm{~Hz}, \mathrm{H}-2^{\prime}\right), 6.44$ (d, $\left.J=16.0 \mathrm{~Hz}, \mathrm{H}-3^{\prime}\right), 7.53\left(\mathrm{H}^{\prime} 5^{\prime}, \mathrm{H}-\right.$ 9'), 7.38 (H-6', H-8'), 7.38 (H-7'); ${ }^{13} \mathrm{C}-\mathrm{NMR}\left(125 \mathrm{MHz}, \mathrm{CDCl}_{3}\right) \delta$ : 38.5 (C-1), 23.7 (C-2), 81.0 (C-3), 37.9 (C-4), 55.2 (C-5), 18.3 (C6), 32.9 (C-7), 40.0 (C-8), 47.6 (C-9), 36.8 (C-10), 23.4 (C-11), 124.3 (C-12), 139.6 (C-13), 42.0 (C-14), 26.6 (C-15), 28.12 (C16), 33.7 (C-17), 59.0 (C-18), 39.6 (C-19), 39.8 (C-20), 32.4 (C21), 41.5 (C-22), 28.09 (C-23), 16.86, 16.90 (C-24, C-26), 15.6 (C-25), 23.2 (C-27), 28.7 (C-28), 17.5 (C-29), 21.4 (C-30), 166.8 (C-1'), 144.2 (C-2'), 118.8 (C-3'), 134.5 (C-4'), 128.0 (C-5', C-9'), 128.8 (C-6', C-8'), 130.1 (C-7').

\section{$\beta$-Amyrin cinnamate (4b)}

${ }^{1} \mathrm{H}$ NMR (500 MHz, $\left.\mathrm{CDCl}_{3}\right): \delta 4.63(\mathrm{t}, J=6.0 \mathrm{~Hz}, \mathrm{H}-3)$, 5.17 (t, $J=3.7 \mathrm{~Hz}, \mathrm{H}-12), 0.90$ (s, Me-23), 0.93 (s, Me-24), 0.97 (s, Me-25), 0.96 (s, Me-26), 1.13 (s, Me-27), 0.82 (s, Me-28), 0.86 (s, Me-29), 0.85 (s, Me-30), 7.65 (d, $J=16.0 \mathrm{~Hz}, \mathrm{H}-2$ '), 6.43 (d, $J$ = 16.0 Hz, H-3'), 7.53 (H-5', H-9'), 7.37 (H-6', H-8'), 7.37 (H-7'); ${ }^{13} \mathrm{C}-\mathrm{NMR}\left(125 \mathrm{MHz}, \mathrm{CDCl}_{3}\right) \delta: 38.3$ (C-1), 23.7 (C-2), $81.0(\mathrm{C}-3)$, 37.9 (C-4), 55.2 (C-5), 18.3 (C-6), 32.6 (C-7), 39.8 (C-8), 47.5 (C9), 38.5 (C-10), 23.5 (C-11), 124.3 (C-12), 139.6 (C-13), 41.7 (C14), 26.1 (C-15), 26.9 (C-16), 32.5 (C-17), 59.0 (C-18), 46.8 (C19), 31.1 (C-20), 34.7 (C-21), 37.1 (C-22), 28.1 (C-23), 16.9 (C24), 15.7 (C-25), 16.8 (C-26), 26.0 (C-27), 28.4 (C-28), 33.3 (C29), 23.7 (C-30), 166.8 (C-1'), 144.3 (C-2'), 118.8 (C-3'), 134.5 (C4'), 128.0 (C-5', C-9'), 128.8 (C-6', C-8'), 130.1 (C-7').

\section{Squalene (5)}

${ }^{1} \mathrm{H}$ NMR $\left(500 \mathrm{MHz}, \mathrm{CDCl}_{3}\right): \delta 5.08-5.13(6 \mathrm{H} .=\mathrm{CH})$, 1.58 (18H, allylic Me, cis), 1.66 (6H, allylic Me, trans), 1.94-2.07 $\left(20 \mathrm{H}\right.$, allylic $\left.\mathrm{CH}_{2}\right)$.

\section{Hydrocarbons \\ ${ }^{1} \mathrm{H}$ NMR (500 MHz, $\mathrm{CDCl}_{3}$ ): $\delta 1.23$ (br s), 0.85 (t, 6.5 \\ $\mathrm{Hz})$.}

\section{RESULTS AND DISCUSSION}

Silica gel chromatography of the dichloromethane extracts of $H$. buotii yielded taraxerone (1) (Ragasa and Cornelio, 2013a), taraxerol (2) (Tareq et al., 2009; Ragasa et al., 2014), and a mixture of $\beta$-sitosterol (3a) (Ragasa et al., 2013b) and stigmasterol (3b) (Ragasa et al., 2013b) from the roots and stems; another mixture of $\alpha$-amyrin cinnamate (4a) (Akihisa et al., 2010) and $\beta$-amyrin cinnamate (4b) (Akihisa et al., 2010) from the flowers; and 3a, squalene (5) (Ragasa et al., 2014b), and saturated hydrocarbons (Ragasa et al., 2015) from the leaves. The structures of 1-5 and saturated hydrocarbons were identified by comparison of their NMR data with those reported in the literature.

The dichloromethane extracts of $H$. buotii yielded taraxerone (1), taraxerol (2), and a mixture of $\beta$-sitosterol (3a) and stigmasterol (3b) from the roots and stems; another mixture of $\alpha$ amyrin cinnamate (4a) and $\beta$-amyrin cinnamate $(\mathbf{4 b})$ from the flowers; and 3a, squalene (5), and hydrocarbons from the leaves. These results indicate that $H$. buotii shares similar chemical characteristics with other members of the genus Hoya: H. wayetii which yielded $\beta$-amyrin cinnamate (4a) and taraxerol (2) (Ebajo et al., 2015b); H. mindorensis (Ebajo et al., 2014), H. multiflora (Ebajo et al., 2015a) and H. wayetii (Ebajo et al., 2015b) which contained $\beta$-sitosterol and stigmasterol; and H. mindorensis (Ebajo et al., 2014) and H. multiflora (Ebajo et al., 2015a) which afforded squalene.

\section{CONFLICTS OF INTEREST}

The authors declare no conflicts of interest.

\section{ACKNOWLEDGMENT}

A research grant from the De La Salle University Science Foundation through the University Research Coordination Office is gratefully acknowledged

\section{REFERENCES}

Akihisa T, Kojima N, Kikuchi T, Yasukawa K, Tokuda H, Masters ET, Manosroi A, Manosroi J. Anti-inflammatory and chemopreventive effects of triterpene cinnamates and acetates from shea fat. J Oleo Sci, 2010; 59(6):273-280.

Aurigue FB. 2013. A Collection of Philippine Hoyas and Their Culture, Philippine Council for Agriculture, Aquatic and Natural Resources Research and Development (PCAARRD). Department of Science and Technology (DOST). 195 pages.

Ebajo Jr VD, C-C Shen, Ragasa CY. Triterpenes and sterol from Hoya mindorensis. Der Pharma Chemica, 2014; 6(4):321-325.

Ebajo Jr VD, Shen C-C, Ragasa CY. Terpenoids and sterols from Hoya multiflora Blume. J Appl Pharm Sci, 2015a; 5(3):33-39.

Ebajo Jr VD, Aurigue FB, Brkljača R, Urban S, Ragasa CY. Chemical constituents of Hoya wayetii Kloppenb. Int J Pharmacog Phytochem Res, 2015b.

Ragasa CY, Cornelio K. Triterpenes from Euphorbia hirta and their cytotoxicity. Chin J Nat Med, 2013a; 11(5):528-533.

Ragasa CY, Torres OB, Tongco JVV, Razal RA, Shen C-C. Chemical constituents of Petersianthus quadrialatus Merr. Res J Pharm Biol Chem Sci, 2014a; 5(4):181-186.

Ragasa CY, Lorena GS, Mandia EH, Raga DD, Shen C-C. Chemical constituents of Abrus precatorius. Amer J Essent Oils Nat Prod, 2013b; 1(2):7-10.

Ragasa CY, Ng VAS, De Los Reyes MM, Mandia EH, Oyong GG, Shen C-C. Chemical constituents and cytotoxicity of the leaves of Dysoxylum gaudichaudianum (A. Juss.) Miq. Der Pharma Chemica, 2014b; 6(5):182-187.

Ragasa CY, Medecilo MP, Shen C-C. Chemical constituents of Moringa oleifera Lam. leaves. Der Pharma Chemica, 2015; 7(7): 395-399.

Tareq FS, Sohrab MdH, Chowhdury AMSU, Afroz F, AlMansur M, Hasan CM. Phytochemical studies on the leaves of Xylia dolabriformis. Dhaka Univ J Pharm Sci, 2009; 8(2):171-172.

\section{How to cite this article:}

Hoya buotii, Apocynaceae, taraxerone, taraxerol, $\beta$-sitosterol, stigmasterol, $\alpha$-amyrin cinnamate, $\beta$-amyrin cinnamate, squalene. Chemical Constituents of Hoya buotii Kloppenb. J App Pharm Sci, 2015; 5 (11): 069-072. 